Cerebrovascular Diseases 中文目录 2006 年第 22 卷第 1 期

Table of Contents Vol.22, No. 1, 2006

翻译 许剑 审校 刘新峰 徐格林 (南京军区南京总医院神经内科, 南京大学医学院)

Translated by Jian Xu and supervised by Xinfeng Liu, Gelin Xu, Dept. Neurology, Nanjing Jinling Hospital, School of Medicine, Nanjing University

目前此翻译内容仅包括自 2004 年以来的《脑血管病》杂志目录。

For the moment, this translation service includes only the Table of Contents from

CEREBROVASCULAR DISEASES and starts with the first issue of the year 2004.

\title{
评论 Editorial
}

1 双嘧达莫加阿司匹林: 非心源栓子性局灶脑缺血后卒中预防的最佳治疗方案

Dipyridamole plus Aspirin: The Best Regimen for Stroke Prevention after Noncardioembolic Focal Cerebral Ischemia

Jonas, S. ; Grieco, G.

Cerebrovasc Dis 2006;22:1-3

\section{论著 Original Paper}

4 华法林与阿司匹林在预防卒中复发或死亡方面的比较: 华法林-阿司匹林影响卒中再发研究 的亚群分析

Comparison of Warfarin versus Aspirin for the Prevention of Recurrent Stroke or Death: Subgroup Analyses from the Warfarin-Aspirin Recurrent Stroke Study

Sacco, R.L. ; Prabhakaran, S. ; Thompson, J.L.P. ; Murphy, A. ; Sciacca, R.R. ; Levin, B. ; Mohr, J.P. ; on behalf of the WARSS Investigators,

Cerebrovasc Dis 2006;22:4-12

13 影响动脉性缺血性卒中儿童患者凝血蛋白及高半胱氨酸代谢的基因突变和多态性研究 Mutations and Polymorphisms in Genes Affecting Hemostasis Proteins and Homocysteine Metabolism in Children with Arterial Ischemic Stroke

Komitopoulou, A. ; Platokouki, H. ; Kapsimali, Z. ; Pergantou, H. ; Adamtziki, E. ; Aronis, S.

Cerebrovasc Dis 2006;22:13-20

21 内科医师的专业特长对卒中患者 30 天存活率及再入院率的影响

30-Day Survival and Rehospitalization for Stroke Patients According to Physician Specialty

Smith, M.A. ; Liou, J.-I. ; Frytak, J.R. ; Finch, M.D.

Cerebrovasc Dis 2006;22:21-26

27 缺血性卒中后迟发的短暂的神经功能损伤恶化

Delayed Transient Worsening of Neurological Deficits after Ischaemic Stroke

De Reuck, J. ; De Groote, L. ; Van Maele, G.

Cerebrovasc Dis 2006;22:27-32

33 青年成人基底节-丘脑出血: 一项基于医院的研究

Basal Ganglia-Thalamic Hemorrhage in Young Adults: A Hospital-Based Study

Chen, Y.-C. ; Wu, Y.-R. ; Hsu, W.-C. ; Chen, C.-M. ; Lee, T.-H. ; Chen, S.-T.

Cerebrovasc Dis 2006;22:33-39

40 非破裂性颅内动脉瘤手术夹闭和血管内弹簧圈填塞直接费用的比较 
Direct Costs of Surgical Clipping and Endovascular Coiling of Unruptured Intracranial Aneurysms Halkes, P.H.A. ; Wermer, M.J.H. ; Rinkel, G.J.E. ; Buskens, E.

Cerebrovasc Dis 2006;22:40-45

46 从人群中篮选的二型糖尿病患者脑血管贮备功能没有降低

Cerebrovascular Reserve Capacity Is Preserved in a Population-Based Sample of Patients with Type 2 Diabetes Mellitus

van Oers, C.A.M.M. ; Manschot, S.M. ; van uffelen, A.C. ; Kappelle, L.J. ; Biessels, G.J. ; 1>on

behalf of the Utrecht Diabetic Encephalopathy Study Group1,

Cerebrovasc Dis 2006;22:46-50

\section{1 早期和晚期血管再通对大脑中动脉近端闭塞引起的梗死形态的影响}

Effect of Early and Delayed Recanalization on Infarct Pattern in Proximal Middle Cerebral Artery

Occlusion

Humpich, M. ; Singer, O.C. ; du Mesnil de Rochemont, R. ; Foerch, C. ; Lanfermann, H. ; Neumann-

Haefelin, T.

Cerebrovasc Dis 2006;22:51-56

57 抗血小板药西洛他唑可有效预防缺血性卒中患者康复期肺炎的发生

Antiplatelet Cilostazol Is Effective in the Prevention of Pneumonia in Ischemic Stroke Patients in the Chronic Stage

for\%20the\%20csps\%20group>Shinoharafor the CSPS group, Y. ; for the CSPS group,

Cerebrovasc Dis 2006;22:57-60

综述 Review

61 卒中后痴呆

Poststroke Dementia

Hénon, H. ; Pasquier, F. ; Leys, D.

Cerebrovasc Dis 2006;22:61-70

\section{病例报道 Case Report}

71 肺结节病患者的烟雾样血管畸形

Moyamoya-Like Vascular Abnormality in Pulmonary Sarcoidosis

Kim, J.S. ; No, Y.J. ;

Cerebrovasc Dis 2006;22:71-7 